\title{
Effects of TSH on the function of human umbilical vein endothelial cells
}

\author{
Limin Tian, ${ }^{1, *}$, Luyan Zhang ${ }^{1, *}$, Jing Liu', Tiankang Guo ${ }^{2}$, Cuixia Gao ${ }^{3}$ and Jing $\mathrm{Ni}^{1}$ \\ Departments of ${ }^{1}$ Endocrinology, ${ }^{2}$ General Surgery, and ${ }^{3}$ Ultrasonography, Gansu Provincial Hospital, \\ 204 Dong Gang West Road, Lanzhou 730000, China \\ *( L Tian and L Zhang contributed equally to this work)
}

Correspondence should be addressed

to J Liu

Email

tIm7066@sina.com

\begin{abstract}
Recent studies have reported that subclinical hypothyroidism $(\mathrm{SCH})$ is associated with atherosclerosis (AS). Thyroid hormone is maintained at normal levels in patients with $\mathrm{SCH}$, whereas TSH is increased. However, the pathogenesis of AS in association with SCH is only partially understood. In addition, endothelial dysfunction plays an important role in the development of AS. The purpose of the present research was to study the direct effect of TSH on human umbilical vein endothelial cells (HUVECs). The expression of some genes associated with endothelial dysfunction after treatment with TSH was evaluated by real-time PCR and western blotting respectively. At first, we showed that the TSH receptor (TSHR) is expressed in HUVECs. We also provide evidence indicating that TSH treatment promotes tumor necrosis factor $\alpha$-induced endothelial cells interactions by upregulating the expression of the adhesion molecules intercellular adhesion molecule-1. Furthermore, the expression of endothelial nitric oxide synthase (eNOS) and prostacyclin $\left(\mathrm{PGI}_{2}\right)$ was significantly attenuated following treatment with TSH in dose- and time-dependent manner. Conversely, the results indicated that TSH upregulated endothelin-1 (ET1) mRNA and protein expression in HUVECs, similar effects were observed for plasminogen activator inhibitor-1 (PA/1) after treatment with various concentrations of TSH. Taken together, these results demonstrate that elevated TSH can promote endothelial dysfunction by altering gene expression in HUVECs.
\end{abstract}

\section{Key Words \\ - thyroid-stimulating hormone \\ - human umbilical vein endothelial cells \\ - subclinical hypothyroidism \\ - atherosclerosis}

Journal of Molecular

Endocrinology

(2014) 52, 215-222

\section{Introduction}

Hypothyroidism is associated with an increased risk for cardiovascular events resulting from atherosclerosis (AS; Cappola 2003). The pathogenesis of AS in association with hypothyroidism is complex and not yet completely understood. It has been suggested that hypercholesterolemia, hypertension, and impaired endothelial function are involved. The traditional theory held that insufficient thyroid hormone (TH) caused AS (Ichiki 2010). However, subclinical hypothyroidism ( $\mathrm{SCH}$ ) has also been related with AS (Valentina et al. 2011). TH is maintained at normal levels in patients with $\mathrm{SCH}$, whereas thyroid-stimulating hormone (TSH) is increased. It remains unclear whether elevated serum TSH can promote endothelial dysfunction and accelerate AS.

The central events of AS include endothelial dysfunction (Atochin \& Huang 2010), inflammation, and vascular smooth muscle cells (VSMCs) proliferation. It is worth noting that endothelial cell dysfunction is generally accepted as an early step in the pathogenesis of AS, and impaired endothelial function has also been

Published by Bioscientifica Ltd 
reported in patients with TH deficiency (Taddei et al. 2003, Biondi et al. 2009). Endothelial dysfunction, which is characterized by an imbalance between relaxing and contracting factors, between procoagulant and anticoagulant substances, and between proinflammatory and anti-inflammatory mediators, plays a particularly significant role in the pathogenesis of AS (Poredos 2002). Furthermore, inflammation plays a major role in the development of AS (Ross 1999). Endothelial dysfunction is also related to increased platelet adherence and smooth muscle cell migration and proliferation, both of which are involved in atherogenesis (Luescher \& Barton 1997). Thus, endothelial dysfunction is the first step in coronary arteriosclerosis (Vanhoutte 2009). The endothelium synthesizes and releases several vasodilating and vasoconstricting factors, including nitric oxide (NO), prostacyclin $\left(\mathrm{PGI}_{2}\right)$, endothelin-1 (ET1), and plasminogen activator inhibitor-1 (PAI1), and both types are associated with AS (Blann \& Taberner 1995). NO and $\mathrm{PGI}_{2}$ synergistically inhibit platelet aggregation, whereas ET1 is a vasoactive peptide and one of the most potent known endogenous vasoconstrictor substances. Moreover, PAI1 is the central component of the fibrinolytic system and is a physiological inhibitor of plasminogen activators. Similarly, the expression of intercellular adhesion molecule-1 (ICAM1), an important adhering molecule, on the endothelial cells can be induced by proinflammatory cytokines, such as tumor necrosis factor $\alpha$ (TNF $\alpha$ ). This process is crucial to facilitate the recruitment of inflammatory cells to the sites of AS, driving atherosclerotic pathogenesis.

The TSH receptor (TSHR) is expressed on thyroid cells and plays a central role in upregulating the function of the thyroid, including the synthesis of TH. Increasing evidence indicates that TSHR is also expressed by many nonthyroid tissues and cells, such as immunocyte, adipose tissue, and bone, in which it may actually play a physiological role (Williams 2011). Our previous study has shown that TSH, by binding to the TSHR on hepatocytes, plays an important role in cholesterol synthesis in the liver and elevating total cholesterol levels in the blood (Zhang et al. 2009, Tian et al. 2010), which is an independent risk factor for AS. It has been shown that the TSHR is expressed on vascular endothelial cells (Donnini et al. 2003). Furthermore, TSH increases the cAMP concentration in vascular endothelial cells (Balzan et al. 2012). In this study, we demonstrated that TSHR was expressed in human umbilical vein endothelial cells (HUVECs) and that stimulation of cultured HUVECs with TSH increased the production of cAMP. We further evaluated whether elevated TSH directly promotes endothelial dysfunction and induces AS by altering gene expression in HUVECs.

\section{Subjects and methods}

\section{Materials}

TSH from bovine pituitary glands was purchased from Sigma Company (T8931, Sigma). Bovine TSH was prepared by dissolving $10 \mathrm{mg}$ of TSH in ultrapure water/doubledistilled water by stirring for $1 \mathrm{~h}$ at room temperature. Antibodies against TSHR (ab2812), endothelial NO synthase (eNOS; ab66127), ET1 (ab117757), $\mathrm{PGI}_{2}$ (ab23668), and PAI1 (ab66705) were purchased from Abcam (Hong Kong, China). An RT-PCR kit was purchased from TaKaRa Bio, Inc. (Dalian, China). TNF $\alpha$ was purchased from Sigma Company (T0157, Sigma). All other reagents were of the highest purity that is commercially available.

\section{Cell culture}

Human umbilical cords were obtained from normal placentas. The umbilical vein was cannulated with blunt needles and perfused to wash out all blood. A $0.1 \%$ collagenase solution was then injected into the vein, which was incubated at $37^{\circ} \mathrm{C}$ for $15 \mathrm{~min}$. The reaction was halted by adding complete medium containing DMEM with heatinactivated $10 \%$ fetal bovine serum, $0.8 \mathrm{mg} / \mathrm{ml}$ human epidermal growth factor, $90 \mathrm{mg} / \mathrm{ml}$ heparin, $100 \mathrm{IU} / \mathrm{ml}$ penicillin, and $100 \mathrm{mg} / \mathrm{ml}$ streptomycin and the vein was incubated in a $5 \% \mathrm{CO}_{2}$ and $95 \%$ air incubator at $37^{\circ} \mathrm{C}$. A human thyroid follicular epithelial cell line (Nthy-ori 3-1) was purchased from the Shanghai Institute of Biochemistry and Cell Biology (Shanghai, China). Nthy-ori 3-1 cells were cultured in $25 \mathrm{~cm}^{2}$ flasks at $37{ }^{\circ} \mathrm{C}$ in a $5 \% \mathrm{CO}_{2}$-humidified incubator and were maintained in RPMI 1640 culture medium supplemented with $10 \%$ fetal bovine serum. These studies were approved by the Ethics Committee of Lanzhou Medical College. The cells were confirmed to be HUVECs based on their typical cobblestone morphology and positivity for factor VIII antigen by immunohistochemical staining. For all experiments, passages 2-5 of HUVECs were used (Gödecke et al. 2012). When treated with TSH or other reagents, the cells were cultured in serum-free medium.

\section{ELISA}

Variation in the cAMP concentration was measured using the cAMP Direct Immunoassay Kit (BioVision, k371-100;

Published by Bioscientifica Ltd. 
Milpitas, CA, USA). Briefly, the cells were stimulated with different TSH concentrations. Subsequently, neutralizing buffer and acetylation reagent mixture were added to the cell lysates. Each acetylated sample and standards were transferred to a protein G-coated white 96-well plate. Rabbit anti-cAMP polyclonal antibody was added to standard and samples, and the reaction mixtures were incubated for $1 \mathrm{~h}$ at room temperature, reincubated with cAMP-HRP for $1 \mathrm{~h}$. The reaction was stopped by adding $1 \mathrm{M} \mathrm{HCl}$ and cAMP levels were determined spectrophotometrically (optical density $450 \mathrm{~nm}$ ). The kit can detect 0.02-2 $\mu \mathrm{M}$ cAMP samples.

Determination of ICAM1 expression using ELISA (Bender Abnova, H00003383 Taipei City, Taiwan). HUVECs were seeded on sterile slide cover slips in 96-well plates overnight and pretreated with TSH before stimulated with TNF $\alpha$. After washing with PBS, monoclonal anti-human CD54 (ICAM1) domain D1 was added and incubated for $1 \mathrm{~h}$ at $37^{\circ} \mathrm{C}$. Goat anti-mouse IgG HRP was then added and incubated for $1 \mathrm{~h}$ at $37^{\circ} \mathrm{C}$. The cells were washed with PBS and incubated with $3,3^{\prime}, 5,5^{\prime}$ tetramethylbenzidine as the substrate for $15 \mathrm{~min}$ at room temperature. The enzyme-substrate reaction was stopped by adding $0.5 \mathrm{M}$ sulfuric acid. The absorbance was measured at $450 \mathrm{~nm}$. The kit assay range is $20-400 \mathrm{ng} / \mathrm{l}$. Each experiment was repeated three times in triplicate samples.

\section{Quantitative real-time PCR assays}

The cells were harvested after $6,12,24$, and $48 \mathrm{~h}$ of stimulation. Total RNA was initially extracted using RNAiso Plus (TaKaRa Biotechnology) according to the manufacturer's instructions. The RNA concentration was determined using a spectrophotometer (Beckman Instruments, Caguas, Puerto Rico). RNA from each sample was reverse transcribed to cDNA and amplified in a total volume of $10 \mu \mathrm{l}$ using a TaKaRa RNA PCR Kit (TaKaRa Biotechnology). Quantitative real-time PCR analyses were performed using a LightCycler Real-Time PCR System (Roche 480). PCR was performed for 40 cycles with an initial denaturing step at $95^{\circ} \mathrm{C}$ for $10 \mathrm{~s}$, annealing at $60^{\circ} \mathrm{C}$ for $30 \mathrm{~s}$, and extension at $72^{\circ} \mathrm{C}$ for $1 \mathrm{~min}$. The reaction was terminated by a cooling step at $4{ }^{\circ} \mathrm{C}$. A melting curve was then constructed to confirm the formation of the intended PCR products. Each reaction was performed in triplicate. In short, the $20 \mu \mathrm{l}$ included $10 \mu \mathrm{l}$ of SYBR mix, $2 \mu \mathrm{l}$ of DNA template, $0.8 \mu \mathrm{l}$ of the relevant primer solution, and Milli-Q water to make up the final volume. The primer sequences used are presented in Table 1.
Table 1 Sequence of the primer used for RT-PCR

\begin{tabular}{|c|c|c|}
\hline Gene & Primer & GenBank \\
\hline eNOS & $\begin{array}{l}\text { Forward: 5'-GGGTATGCCTTG- } \\
\text { GACTTTGGAA-3' } \\
\text { Reverse: 5'-CATGGAAGTC- } \\
\text { GAGCCTGGTG-3' }\end{array}$ & NM_000603.4 \\
\hline$E T 1$ & $\begin{array}{l}\text { Forward: 5'-TCAGAGGAACACC- } \\
\text { TAAGACAAACCA-3' } \\
\text { Reverse: } 5^{\prime} \text {-CCCGAAGGTCTGTCAC- } \\
\text { CAAT-3' }\end{array}$ & NM_001955.4 \\
\hline $\mathrm{PGI}_{2}$ & $\begin{array}{l}\text { Forward: 5'-GGGTATGCCTTG- } \\
\text { GACTTTGGAA-3' } \\
\text { Reverse: 5'-CATGGAAGTC- } \\
\text { GAGCCTGGTG-3' }\end{array}$ & NM_000960.3 \\
\hline PAl1 & $\begin{array}{l}\text { Forward: } 5^{\prime}-\text { GATGGCTCGACCAA- } \\
\text { CAAGTTCA-3' } \\
\text { Reverse: } 5^{\prime}-\text { GGGCAGTTC- } \\
\text { CAAAATGTCGTA-3' }\end{array}$ & NM_000602.3 \\
\hline$\beta$-actin & $\begin{array}{l}\text { Forward: } 5^{\prime}-\text { TGGCACCCAGCACAAT- } \\
\text { GAA-3' } \\
\text { Reverse: } 5^{\prime} \text {-CTAAGTCATAGTCCGCC- } \\
\text { TAGAAGCA-3' }\end{array}$ & NM_001101.3 \\
\hline
\end{tabular}

\section{Western blot analysis}

For western blot analysis, the total protein concentration of cells was determined using a bicinchoninic acid protein assay kit (Pierce, Rockford, IL, USA). Whole-cell lysates were separated by $8-10 \%$ SDS-PAGE and transferred onto Immobilon PVDF membranes (Millipore, Billerica, MA, USA). The membranes were blocked for $2 \mathrm{~h}$ in a solution of 5\% powdered skimmed milk in Tris-buffered saline and incubated overnight at $4{ }^{\circ} \mathrm{C}$ with primary antibodies against $\beta$-actin (1:2000), TSHR (1:500), eNOS (1:1000), ET1 (1:2500), PGI 2 (1:250), or PAI1 (1:1000). The membranes were then incubated with secondary antibody (1:2000) for $2 \mathrm{~h}$. Bands were detected using the ECL detection system. The experiments were repeated three times.

\section{Statistical analysis}

The data were analyzed using SPSS (Statistical Package for the Social Sciences), 19.0 (SPSS, Inc.) and expressed as the mean \pm s.D. Differences between means values were compared using either unpaired Student's t-tests for twogroup comparisons or one-way ANOVA (Dunnett's $t$ or least significant difference (LSD) test) for multiple comparisons. $P$ values $<0.05$ were considered statistically significant.

\section{Results}

\section{Presence of TSHR in HUVECs}

The presence of the TSHR on HUVECs was confirmed by western blot analysis (Fig. 1), which showed a clear band of

Published by Bioscientifica Ltd 
A
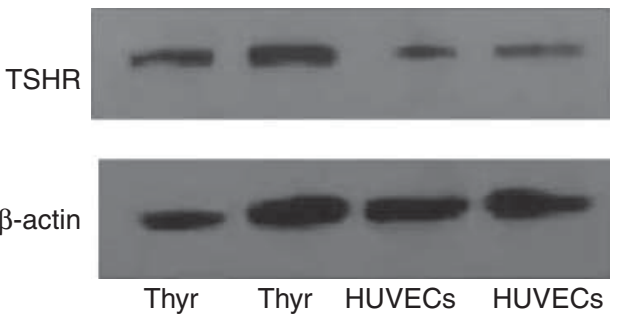

B

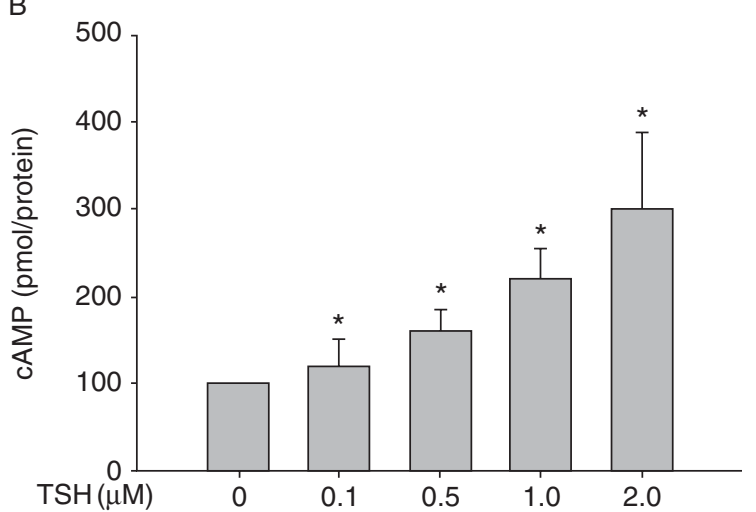

\section{Figure 1}

Presence of TSHR in HUVECs. (A) TSHR expression was detected by western blotting of HUVECs and human thyroid tissue $(62 \mathrm{kDa}$, see also Supplementary Fig. 1, see section on supplementary data given at the end of this article); $\beta$-actin was used as a housekeeping protein. Results are representative of three independent experiments. (B) The cells were stimulated with TSH $(0,1$, and $2 \mu \mathrm{M})$ for $1 \mathrm{~h}$, and intracellular cAMP levels were assayed. ${ }^{*} P<0.05$ vs control.

$\sim 62 \mathrm{kDa}$ corresponding to the molecular mass of the TSHR protein. The TSHR protein expression was observed at a lower level on HUVECs when compared with thyroid tissue. Moreover, we further examined and demonstrated the functional coupling of the TSHR with cAMP levels in HUVECs using increasing TSH concentrations. Treatment with TSH significantly stimulated cAMP production in HUVECs compared with the control (Fig. 1B; $P<0.05$ ). Additionally, pretreatment of HUVECs with $2 \mu \mathrm{M}$ TSH increased the cAMP level by approximately twofold over the cAMP level induced by $1 \mu \mathrm{M}$ TSH.

\section{TSH enhances the TNF $\alpha$-induced expression of ICAM1 in HUVECS}

To investigate whether TSH could exert an inflammatory effect on endothelial cells, the expression of ICAM1 one of several proinflammatory factors expressed on endothelial cells in response to several inflammatory stimuli was examined after HUVEC stimulation with TNF $\alpha$. The cells were pretreated with various concentrations of TSH $(0.1$, $0.5,1.0$, and $2.0 \mu \mathrm{M}$ ) for $24 \mathrm{~h}$ and subsequently co-treated with TNF $\alpha(10 \mathrm{ng} / \mathrm{ml})$ for $6 \mathrm{~h}$. Whole-cell ELISA demonstrated that TSH markedly improved TNF $\alpha$-induced ICAM1 expression in a concentration-dependent manner (Fig. 2). Pretreatment of endothelial cells with TSH $(2 \mu \mathrm{M})$ significantly increased TNF $\alpha$-induced ICAM1 expression (Fig. 2).

\section{TSH downregulated the mRNA and protein expression of eNOS in cultured HUVECs}

We investigated the influence of TSH on eNOS expression using RT-PCR and western blotting. As shown in Fig. 3A, treatment with $0.1,0.5,1.0$, and $2.0 \mu \mathrm{M}$ TSH for $12 \mathrm{~h}$ reduced eNOS expression. In addition, the decrease in the eNOS mRNA level became evident at $24 \mathrm{~h}$ after treatment with $2.0 \mu \mathrm{M} \mathrm{TSH}$, with a more pronounced effect at $48 \mathrm{~h}$ (Fig. 3B). The expression of eNOS at 12 and $48 \mathrm{~h}$ decreased by 0.64- and 0.76-fold respectively, compared with the controls at $2 \mu \mathrm{M}$ TSH. Western blotting demonstrated the same pattern of change in the eNOS protein level over $48 \mathrm{~h}$ (Fig. 3C). At $48 \mathrm{~h}$, the eNOS protein level gradually decreased as the TSH concentration increased from 0.1 to $1.0 \mu \mathrm{M}$ and to $2.0 \mu \mathrm{M}$ compared with the control group (Fig. 3C). These findings suggest that there is a dose- and time-dependent relationship between TSH and the inhibition of eNOS expression. Taken together, these results indicate that TSH treatment suppressed eNOS expression in cultured HUVECs.

\section{TSH upregulated the mRNA and protein expression of ET1 in cultured HUVECs}

We further investigated the influence of TSH on ET1 expression. HUVECs were pretreated with various

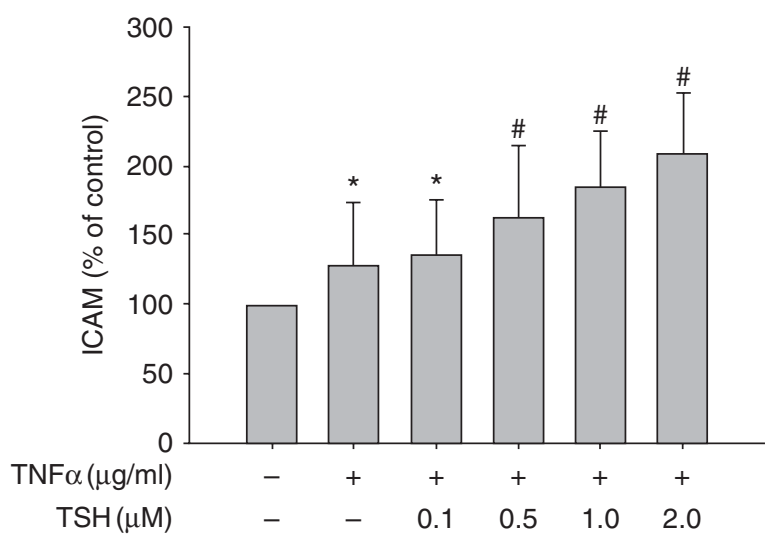

Figure 2

Effects of TSH on ICAM1 expression in HUVECs. Endothelial cells were pretreated with TSH $(0,0.1,0.5,1.0$, and $2.0 \mu \mathrm{M})$ for $24 \mathrm{~h}$ and then stimulated with TNF $\alpha$ for $6 \mathrm{~h}$. The data has been normalized as percentage of control. ${ }^{*} P<0.05$ vs control. ${ }^{\#} P<0.05$ vs TNF $\alpha$.

Published by Bioscientifica Ltd 
A

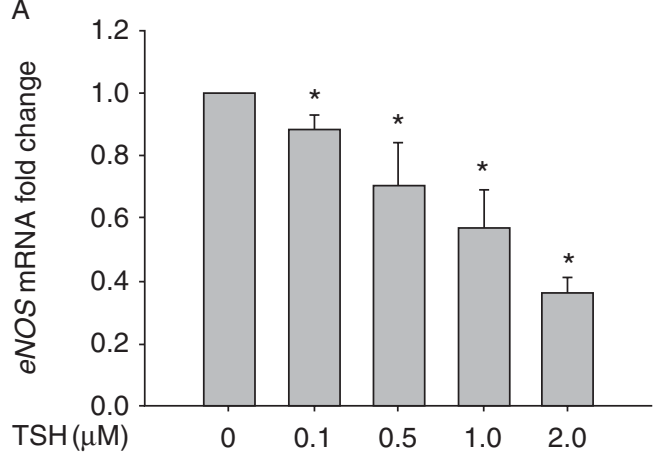

B

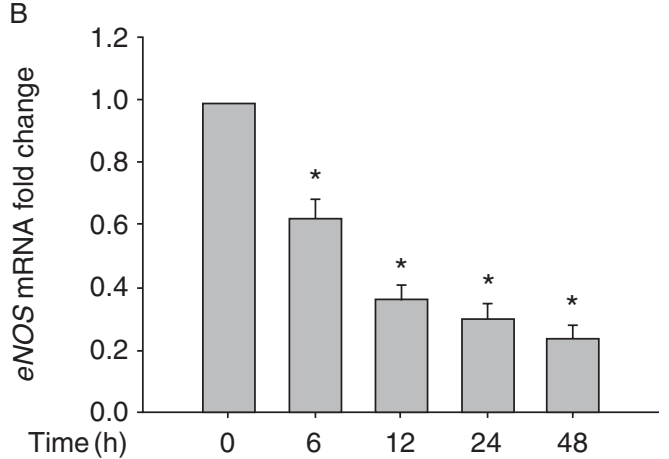

C
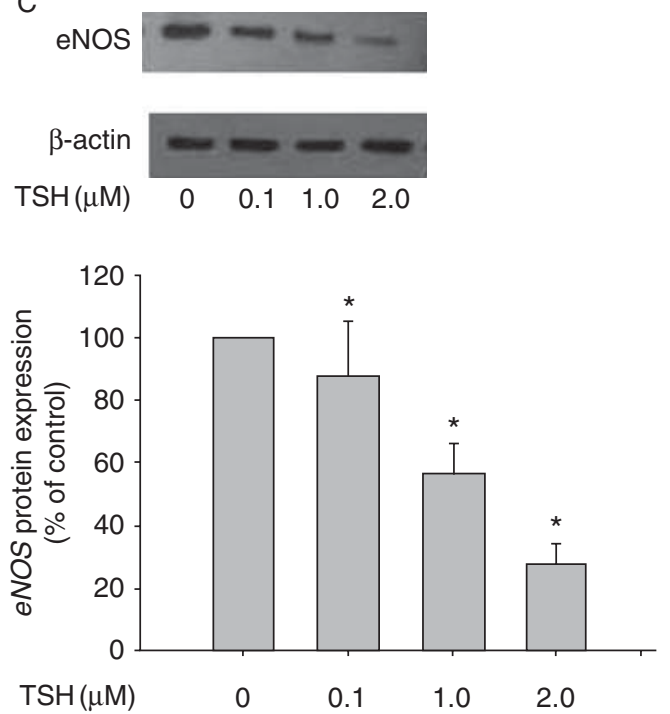

Figure 3

Downregulation of eNOS levels in HUVECs by TSH stimulation. (A) RT-PCR analysis of eNOS mRNA expression following incubation with TSH $(0,0.1$, $0.5,1.0$, and $2.0 \mu \mathrm{M})$ for $12 \mathrm{~h}(n=3)$. $* P<0.05$ vs control. (B) RT-PCR analysis of eNOS mRNA expression following incubation with TSH $(2 \mu \mathrm{M})$ for 0,6 , 12,24 , and $48 \mathrm{~h}(n=3) .{ }^{*} P<0.05$ vs control. (C) Western blotting analysis was performed to examine eNOS protein expression in HUVECs exposed to TSH for $48 \mathrm{~h}$ (140 kDa, see also Supplementary Fig. 2, see section on supplementary data given at the end of this article), and $\beta$-actin was used as a housekeeping protein. The bar plots illustrate a summary of the band intensity data after being normalized to $\beta$-actin, and the data are expressed as the mean percentage of the control. ${ }^{*} P<0.05$ vs control. concentrations of TSH $(0.1-2 \mu \mathrm{M})$ for $12 \mathrm{~h}$, the results showed that TSH notably increased ET1 levels in HUVECs (Fig. 4A). As shown in Fig. 4B, the ET1 (EDN1) mRNA level gradually increased over $0,6,12,24$, and 48 h of treatment with $2 \mu \mathrm{M}$ TSH (Fig. 4B). ET1 protein expression was also detected via western blotting. At $48 \mathrm{~h}$, the ET1 protein level gradually increased with increasing concentrations of TSH $(0.1,1.0$, and $2.0 \mu \mathrm{M}$ ) compared with the control group (Fig. 4C). Corresponding changes were observed in the ET1 mRNA level. These findings indicate that the effects of TSH on ET1 expression occurred in a dose- and time-dependent manner.

\section{TSH downregulated $P G I_{2}$ mRNA and protein expression in cultured HUVECs}

In this study, $\mathrm{PGI}_{2}$ mRNA and protein levels in HUVECs from the TSH-treated and control groups were further investigated using RT-PCR and western blotting (Fig. 5). As shown in Fig. 5, TSH notably decreased the $P G I_{2}$ mRNA and protein levels. In addition, the $\mathrm{PGI}_{2} \mathrm{mRNA}$ levels in each TSH-treated group were decreased to varying degrees (Fig. 5A and B). At $12 \mathrm{~h}$, we observed a dose-dependent decrease in the mRNA expression level of $\mathrm{PGI}_{2}$ after stimulation with different concentrations of TSH (Fig. 5A). Besides, we observed a time-dependent decrease in the mRNA expression of $\mathrm{PGI}_{2}$ after stimulation with TSH (Fig. 5B). Following treatment with TSH $(0.1-2 \mu \mathrm{M})$ for $48 \mathrm{~h}$, the results of western blotting analysis revealed that the pattern of change in $\mathrm{PGI}_{2}$ protein levels was similar to that of the mRNA expression levels (Fig. 5C). These findings indicate that there was a time- and dose-dependent relationship between TSH and the inhibition of $\mathrm{PGI}_{2}$ expression.

\section{TSH upregulated PAI1 (SERPINE1) MRNA and protein expression in cultured HUVECs}

We also investigated the influence of TSH on PAI1 expression. RT-PCR showed that treatment with TSH (0.1, $0.5,1.0$, and $2.0 \mu \mathrm{M})$ for $12 \mathrm{~h}$ increased the expression of PAI1 mRNA in a concentration-dependent manner (Fig. 6A). As shown in Fig. 6B, the PAI1 mRNA levels gradually increased over $0,6,12,24$, and $48 \mathrm{~h}$ of treatment with $2.0 \mu \mathrm{M}$ TSH. Furthermore, compared with the control group, the PAI1 protein levels increased to varying degrees following treatment with different concentrations of TSH $(P<0.05$; Fig. 6C) and showed good agreement with the observed increase in PAI1 mRNA expression. These findings suggest that the induction of PAI1 expression by TSH was dose dependent. In conclusion, our results demonstrate that TSH induces PAI1 expression.

Published by Bioscientifica Ltd 


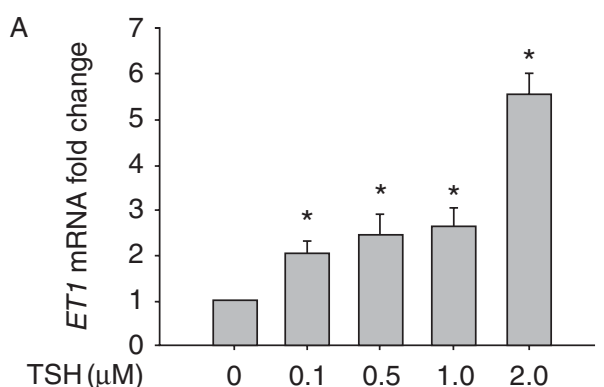

B

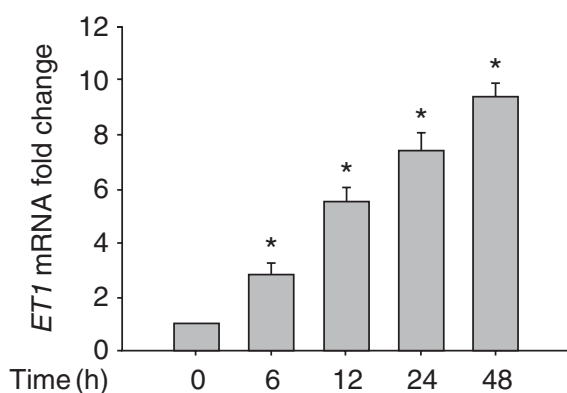

C
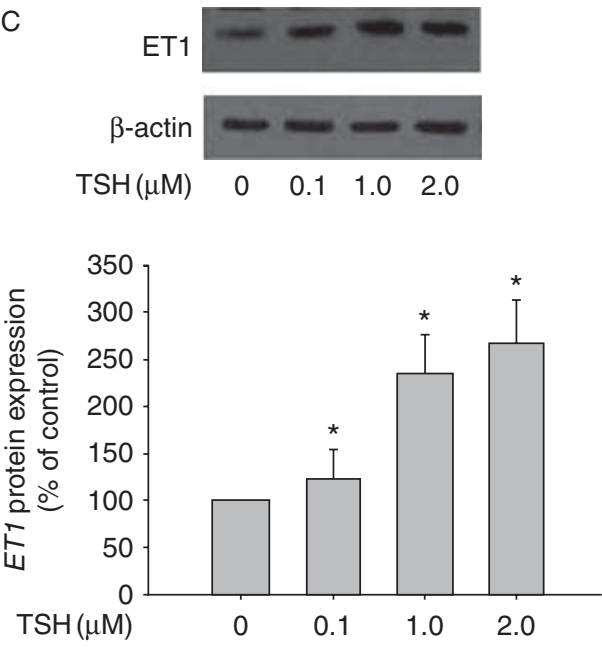

\section{Figure 4}

Upregulation of ET1 levels in HUVECs by TSH stimulation. (A) RT-PCR analysis of ET1 mRNA expression following incubation with TSH $(0,0.1,0.5$, 1.0 , and $2.0 \mu \mathrm{M})$ for $12 \mathrm{~h}(n=3)$. ${ }^{*} P<0.05$ vs control. (B) RT-PCR analysis of ET1 mRNA expression following incubation with TSH $(2 \mu \mathrm{M})$ for $0,6,12,24$, and $48 \mathrm{~h}(n=3)$. ${ }^{*} P<0.05$ vs control. (C) The dose-dependent effects of TSH on ET1 expression at protein levels for $48 \mathrm{~h}$ ( $23 \mathrm{kDa}$, see also Supplementary Fig. 3, see section on supplementary data given at the end of this article). The bar plots show the summarized data of the band intensities after being normalized to $\beta$-actin and are expressed as mean percentage of control. $\star P<0.05$ vs control.

\section{Discussion}

Notably, the TSH concentrations $(0.1-2 \mu \mathrm{M})$ used in this study were higher than those found in the general population and in patients with hypothyroidism, although they were similar to the concentrations used for cultured nonthyrocytes, such as 3T3-L1 preadipocytes (Bell et al. 2002), fibroblasts (Agretti et al. 2005), aortic tissue, and umbilical cord endothelial cells (Balzan et al. 2012). Coexisting growth factors/cytokines, such as insulin-like growth factor 1 , may function synergistically to augment TSH signaling in vivo (Tian et al. 2010), which may account
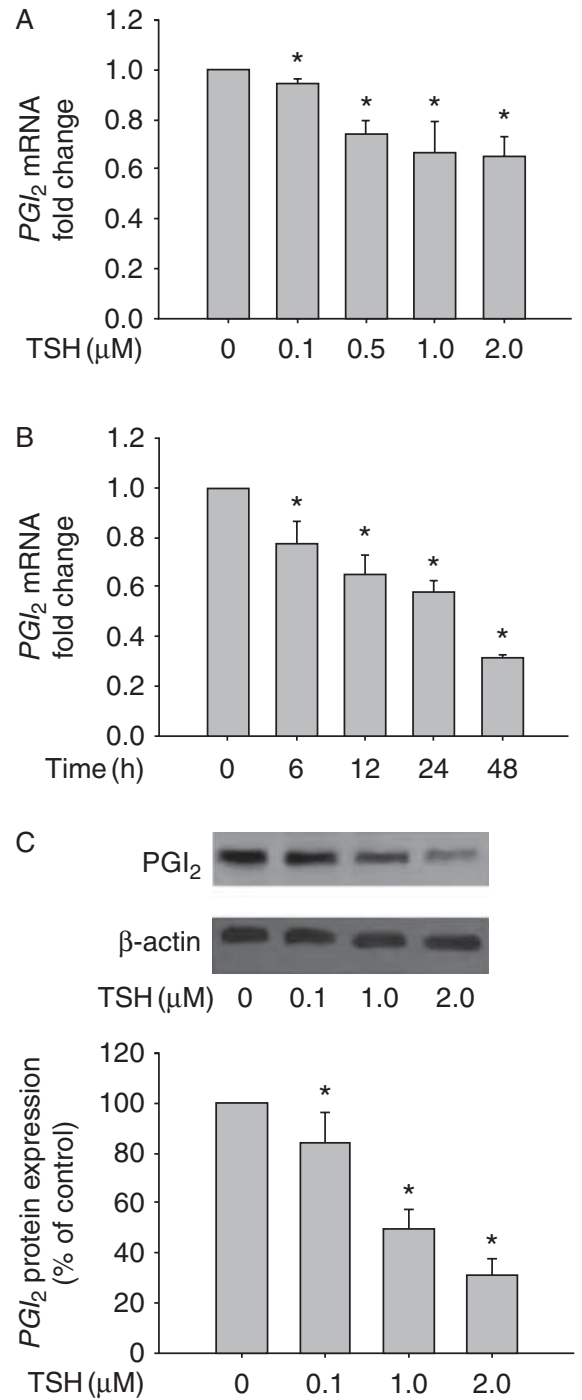

Figure 5

Downregulation of $\mathrm{PGI}_{2}$ levels in HUVECs by TSH stimulation. (A) RT-PCR analysis of $P G I_{2}$ mRNA expression following incubation with TSH $(0,0.1,0.5$, 1.0, and $2.0 \mu \mathrm{M})$ for $12 \mathrm{~h}(n=3)$. ${ }^{*} P<0.05$ vs control. (B) RT-PCR analysis of $P G I_{2}$ mRNA expression following incubation with TSH $(2 \mu \mathrm{M})$ for $0,6,12,24$, and $48 \mathrm{~h}(n=3)$. ${ }^{*} P<0.05$ vs control. (C) The dose-dependent effects of $\mathrm{TSH}$ on $\mathrm{PGl}_{2}$ protein expression at $48 \mathrm{~h}(57 \mathrm{kDa}$, see also Supplementary Fig. 4, see section on supplementary data given at the end of this article). The bar plots illustrate a summary of the band intensity data after being normalized to $\beta$-actin, and the data are expressed as the mean percentage of the control. $* P<0.05$ vs control.

Published by Bioscientifica Ltd. 

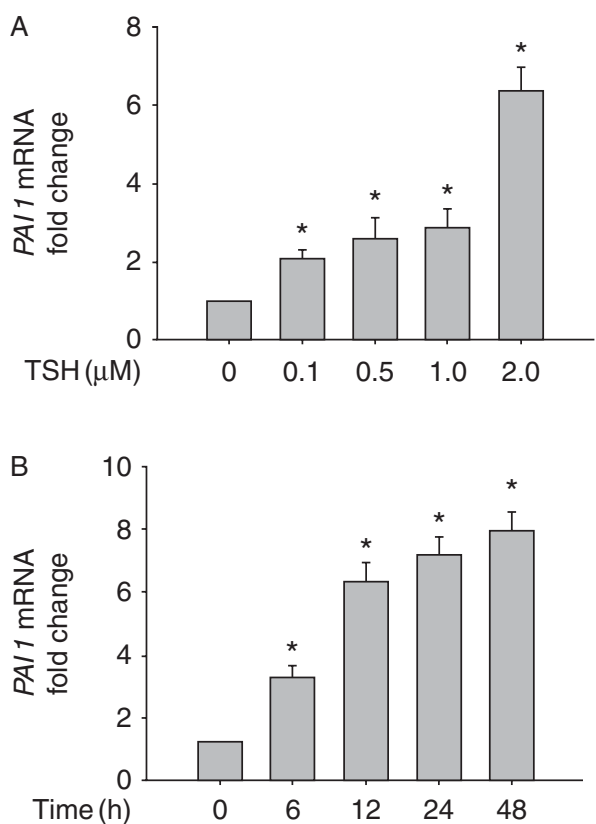

C
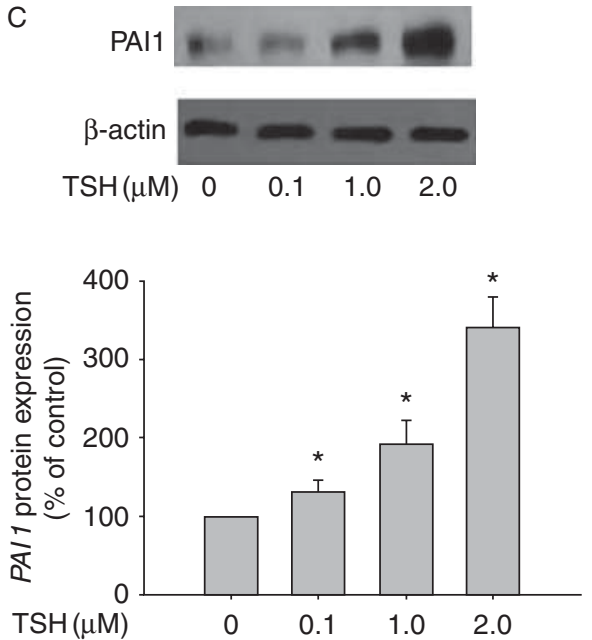

Figure 6

Upregulation of PAI1 levels in HUVECs by TSH stimulation. (A) RT-PCR analysis of PAl1 mRNA expression following incubation with TSH $(0,0.1$, $0.5,1.0$, and $2.0 \mu \mathrm{M})$ for $12 \mathrm{~h}(n=3) . * P<0.05$ vs control. (B) RT-PCR analysis of PAl1 mRNA expression following incubation with TSH $(2 \mu \mathrm{M})$ for $0,6,12$, 24 , and $48 \mathrm{~h}(n=3) . * P<0.05$ vs control. (C) Western blotting analysis was performed to examine PAl1 expression in HUVECs exposed to TSH for $48 \mathrm{~h}$ (45 kDa, see also Supplementary Fig. 5, see section on supplementary data given at the end of this article), and $\beta$-actin was used as a housekeeping protein. The bar plots illustrate a summary of the band intensity data after being normalized to $\beta$-actin, and the data are expressed as the mean percentage of the control. ${ }^{*} P<0.05$ vs control.

for the lower TSH concentration in the human body. Balzan et al. also reported that TSH increased cAMP and eNOS expression in human microvascular endothelial cells (HMEC1). Furthermore, they also observed that TSHR is functional as indicated by the ability of TSH to stimulate
cAMP synthesis in HMEC1 cells. Similarly, to verify the functionality of TSHR in HUVECs, our findings indicate the dose-depended manner of cAMP levels relative to TSH. Although we did not use antagonists, we speculate that elevated TSH levels can promote endothelial dysfunction by binding to the TSHR on HUVECs.

Endothelial dysfunction is an early marker of AS (Davignon \& Ganz 2004) and helps to predict cardiovascular events before they become overt (Bonetti 2002). Endothelial dysfunction is also associated with inflammation, which has been thought to trigger leukocyte adhesion, platelet aggregation, and VSMC proliferation and migration, leading to arterial wall thickening and atherosclerotic lesion formation (Kaperonis et al. 2006). During the inflammation process, the interaction of monocytes with the arterial wall is mediated by adhesion molecules, such as VCAM1, expressed on the surface of endothelial cells. Moreover, the expression of ICAM1 is commonly upregulated by proinflammatory cytokines such as interleukin 1 and TNF $\alpha$ (Pober et al. 1986, Marui et al. 1993). Our study determined that TSH treatment promotes TNF $\boldsymbol{\alpha}$-induced ICAM1 expression in HUVECs, which suggests that TSH has inflammatory and atherosclerotic functions in HUVECs.

We have previously shown that TSH can act directly on liver cells and may elevate serum total cholesterol levels (Zhang et al. 2009, Tian et al. 2010), which is an independent risk factor for AS. In the current study, we extended these findings and demonstrated that treatment of cultured HUVECs with TSH resulted in significantly lower eNOS and $\mathrm{PGI}_{2}$ expression and higher levels of ET1 and PAI1 when compared with the control group. This effect of TSH was dose dependent and time dependent as well as TSHR dependent.

Consequently, using a range of TSH concentrations to treat HUVECs, we demonstrated that TSH plays important roles in inducing endothelial dysfunction and regulating the development of AS, which indicates a potential mechanism for AS development involving the direct action of TSH on HUVECs. These results may provide novel insights into the development of AS in $\mathrm{SCH}$. The results reveal a potential effect of TSH on HUVECs that has possible pathological and clinical implications for the pathogenesis of AS, particularly its association with hypothyroidism, which is a common human disease that is associated with elevated TSH.

\section{Supplementary data}

This is linked to the online version of the paper at http://dx.doi.org/10.1530/ JME-13-0119.

Published by Bioscientifica Ltc. 


\section{Declaration of interest}

The authors declare that there is no conflict of interest that could be perceived as prejudicing the impartiality of the research reported.

\section{Funding}

This work was supported by the National Natural Science Foundation of China (grant number 81160100) and the Health Planning Project of Gansu province (grant number GSWST2011-01).

\section{Acknowledgements}

The authors thank the teachers in the central laboratory of the First Hospital of Lanzhou University for their excellent technical assistance.

\section{References}

Agretti P, De Marco G, De Servi M, Marcocci C, Vitti P, Pinchera A \& Tonacchera M 2005 Evidence for protein and mRNA TSHr expression in fibroblasts from patients with thyroid-associated ophthalmopathy (TAO) after adipocytic differentiation. European Journal of Endocrinology 152 777-784. (doi:10.1530/eje.1.01900)

Atochin DN \& Huang PL 2010 Endothelial nitric oxide synthase transgenic models of endothelial dysfunction. Pflügers Archiv 460 965-974. (doi:10.1007/s00424-010-0867-4)

Balzan S, Del Carratore R, Nicolini G, Beffy P, Lubrano V, Forini F \& Iervasi G 2012 Proangiogenic effect of TSH in human microvascular endothelial cells through its membrane receptor. Journal of Clinical Endocrinology and Metabolism 97 1763-1770. (doi:10.1210/jc.2011-2146)

Bell A, Gagnon A, Dods P, Papineau D, Tiberi M \& Sorisky A 2002 TSH signaling and cell survival in 3T3-L1 preadipocytes. American Journal of Physiology. Cell Physiology 283 C1056-C1064. (doi:10.1152/ajpcell. 00058.2002)

Biondi B, Galderisi M, Pagano L, Sidiropulos M, Pulcrano M, Arcangelo D, Serena L, Rossi A, Oreste D \& Gaetano L 2009 Endothelial-mediated coronary flow reserve in patients with mild thyroid hormone deficiency. European Journal of Endocrinology 161 323-329. (doi:10.1530/EJE-09-0196)

Blann AD \& Taberner DA 1995 A reliable marker of endothelial cell dysfunction: does it exist? British Journal of Haematology 90 244-248. (doi:10.1111/j.1365-2141.1995.tb05143.x)

Bonetti PO 2002 Endothelial dysfunction: a marker of atherosclerotic risk. Arteriosclerosis, Thrombosis, and Vascular Biology 23 168-175. (doi:10.1161/01.ATV.0000051384.43104.FC)

Cappola AR 2003 Hypothyroidism and atherosclerosis. Journal of Clinical Endocrinology and Metabolism 88 2438-2444. (doi:10.1210/ jc.2003-030398)

Davignon J \& Ganz P 2004 Role of endothelial dysfunction in atherosclerosis. Circulation 109 III27-III32. (doi:10.1161/01.CIR. $0000115644.35804 .8 \mathrm{~B})$
Donnini D, Ambesi-Impiombato FS \& Curcio F 2003 Thyrotropin stimulates production of procoagulant and vasodilatative factors in human aortic endothelial cells. Thyroid 13 517-521. (doi:10.1089/ 105072503322238764)

Gödecke S, Roderigo C, Rose CR, Rauch BH, Gödecke A \& Schrader J 2012 Thrombin-induced ATP release from human umbilical vein endothelial cells. American Journal of Physiology. Cell Physiology 302 C915-C923. (doi:10.1152/ajpcell.00283.2010)

Ichiki T 2010 Thyroid hormone and atherosclerosis. Vascular Pharmacology 52 151-156. (doi:10.1016/j.vph.2009.09.004)

Kaperonis EA, Liapis CD, Kakisis JD, Dimitroulis D \& Papavassiliou VG 2006 Inflammation and atherosclerosis. European Journal of Vascular and Endovascular Surgery 31 386-393. (doi:10.1016/j.ejvs.2005.11.001)

Luescher TF \& Barton M 1997 Biology of the endothelium. Clinical Cardiology 20 (11 Suppl 2) II-3-10.

Marui N, Offermann MK, Swerlick R, Kunsch C, Rosen CA, Ahmad M, Alexander RW \& Medford RM 1993 Vascular cell adhesion molecule-1 (VCAM-1) gene transcription and expression are regulated through an antioxidant-sensitive mechanism in human vascular endothelial cells. Journal of Clinical Investigation 92 1866-1874. (doi:10.1172/ JCI116778)

Pober JS, Gimbrone MA, Lapierre LA, Mendrick DL, Fiers W, Rothlein R \& Springer TA 1986 Overlapping patterns of activation of human endothelial cells by interleukin 1, tumor necrosis factor, and immune interferon. Journal of Immunology 137 1893-1896.

Poredos P 2002 Endothelial dysfunction in the pathogenesis of atherosclerosis. International Angiology 21 109-116.

Ross R 1999 Atherosclerosis - an inflammatory disease. New England Journal of Medicine 340 115-126. (doi:10.1056/NEJM199901143400207)

Taddei S, Caraccio N, Virdis A, Dardano A, Versari D, Ghiadoni L, Salvetti A, Ferrannini E \& Monzani F 2003 Impaired endothelium-dependent vasodilatation in subclinical hypothyroidism: beneficial effect of levothyroxine therapy. Journal of Clinical Endocrinology and Metabolism 88 3731-3737. (doi:10.1210/jc.2003-030039)

Tian L, Song Y, Xing M, Zhang W, Ning G, Li X, Yu C, Qin C, Liu J, Tian X et al. 2010 A novel role for thyroid-stimulating hormone: up-regulation of hepatic 3-hydroxy-3-methyl-glutaryl-coenzyme a reductase expression through the cyclic adenosine monophosphate/protein kinase A/cyclic adenosine monophosphate-responsive element binding protein pathway. Hepatology 52 1401-1409. (doi:10.1002/hep.23800)

Valentina VN, Marijan B, Chedo D \& Branka K 2011 Subclinical hypothyroidism and risk to carotid atherosclerosis. Arquivos Brasileiros de Endocrinologia e Metabologia 55 475-480. (doi:10.1590/S000427302011000700007)

Vanhoutte PM 2009 Endothelial dysfunction: the first step toward coronary arteriosclerosis. Circulation Journal 73 595-601. (doi:10.1253/circj.CJ-08-1169)

Williams GR 2011 Extrathyroidal expression of TSH receptor. Annales d'Endocrinologie 72 68-73. (doi:10.1016/j.ando.2011.03.006)

Zhang W, Tian LM, Han Y, Ma HY, Wang LC, Guo J, Gao L \& Zhao JJ 2009 Presence of thyrotropin receptor in hepatocytes: not a case of illegitimate transcription. Journal of Cellular and Molecular Medicine 13 4636-4642. (doi:10.1111/j.1582-4934.2008.00670.x)

Received in final form 14 January 2014

Accepted 17 January 2014

Accepted Preprint published online 20 January 2014 http://jme.endocrinology-journals.org DOI: 10.1530/JME-13-0119
() 2014 Society for Endocrinology Printed in Great Britain
Published by Bioscientifica Ltd. 